\title{
Osteoporosis: New-Generation Drugs
}

\author{
Heinrich Resch \\ Department II Rheumatology/Osteology and Gastroenterology, KH Barmherzige Schwestern (St. Vincent Hospital), \\ Medical University Vienna, Austria
}

\author{
Key Words \\ Osteoporosis - Postmenopausal osteoporosis . \\ Denosumab · Monoclonal antibody
}

\section{Summary}

A new understanding in the pathophysiology of bone led to the development of a fully human monoclonal antibody directed against RANK ligand (RANKL). Denosumab inhibits the interaction of RANKL with its receptor RANK, thereby suppressing osteoclast differentiation, function and survival. In this respect, denosumab mimics osteoprotegerin, the endogenous antagonist of RANKL. Recently, denosumab has been approved by the European Medicines Agency (EMEA) for the treatment of postmenopausal osteoporosis (PMO) and treatmentinduced bone loss in breast and prostate cancer patients undergoing hormone ablation. Oncologic indications affecting bone are promising, but still under clinical evaluation. In clinical trials for PMO, denosumab has shown significant increases in bone mineral density (BMD) at various skeletal sites, decreases in bone turnover markers, and reductions in fracture risk. In head-tohead studies, denosumab proved to be superior to alendronate with regard to the increase in BMD. Considering clinical trial data, the risk-benefit profile of denosumab seems to be favorable since the rates of adverse events, serious adverse events, infections, malignancies and deaths were not higher compared to the control arms. In PMO, denosumab is applied subcutaneously as a 60-mg dose twice yearly. This administration scheme and route might have a high acceptance by patients and physicians.

\author{
Schlüsselwörter \\ Osteoporose - Osteoporose, postmenopausale . \\ Denosumab · Monoklonaler Antikörper
}

\section{Zusammenfassung}

Ein neues Verständnis der Pathophysiologie des Knochenstoffwechsel mündete in der Entwicklung eines vollhumanen, monoklonalen Antikörpers gegen den RANK-Liganden (RANKL). Denosumab hemmt die Interaktion von RANKL mit seinem Rezeptor RANK, was wiederum Differenzierung, Funktion und Überleben der Osteoklasten hemmt. In dieser Hinsicht ahmt Denosumab die Wirkung von Osteoprotegerin nach, dem physiologisch vorkommenden Antagonisten von RANKL. Denosumab ist seit kurzem von der EMEA (European Medicines Agency) zur Behandlung der postmenopausalen Osteoporose (PMO) und des behandlungsinduzierten Knochensubstanzverlustes während und nach der Hormonablationstherapie bei Mammakarzinomen und Prostatakarzinomen zugelassen. In klinischen Studien bei PMO-Patienten zeigten sich unter Denosumab eine signifikante Erhöhung der Knochenmineraldichte an verschiedenen Messpunkten, eine Verringerung der Knochenstoffwechselparameter und letztlich eine Verringerung des Frakturrisikos. Des Weiteren war Denosumab in Vergleichsstudien mit Alendronat in Bezug auf die Erhöhung der Knochendichte überlegen. Das Risiko-NutzenProfil von Denosumab erscheint nach den klinischen Studien sehr vorteilhaft, da die Rate an unerwünschten und schwerwiegenden unerwünschten Ereignissen nicht höher war als in den Vergleichsarmen. In Studien zur PMO wurde Denosumab subkutan in einer Dosis von 60 mg zweimal jährlich verabreicht. Dieses einfache Verabreichungsschema könnte unter Patienten und Ärzten eine hohe Akzeptanz erlangen.

\section{KARGER}

Fax +497614520714

Information@Karger.de

www.karger.com
(C) 2010 S. Karger GmbH, Freiburg

Accessible online at:

www.karger.com/brc

Prim. Univ.-Prof. Dr. med. Heinrich Resch

Medizinische Universität Wien, KH Barmherzige Schwestern (St. Vincent Hospital) II. Medizinische Abteilung

Stumpergasse 13, 1060 Wien, Austria

Tel. +43 1599 88-2119, Fax -4041

heinrich.resch@bhs.at 


\section{Introduction}

Osteoporosis is characterized by decreased bone density and altered bone microarchitecture, which reduce bone strength and increase the risk of fractures [1]. The major consequences of osteoporosis are fractures that increase mortality and morbidity and have a significant impact on the quality of life. Bone mass declines as people age, and especially postmenopausal women are at high risk. Osteoporosis affects more than 75 million people in the USA, Europe and Japan [2, 3]. Worldwide, the disease causes more than 8.9 million fractures annually, of which more than 4.5 million occur in America and Europe. Approximately one-third of all postmenopausal women worldwide suffer from osteoporosis and 1 in 3 women above the age of 50 suffers a fracture associated with osteoporosis. Combined annual costs of all osteoporotic fractures have been estimated to be $\$ 20$ billion in the USA and about $\$ 30$ billion in the European Union (EU) [3].

Osteoporosis is defined as a bone mineral density (BMD) T-score of less than -2.5 , osteopenia as a BMD T-score between -1.0 and -2.5 [4]. Although there are several drugs available for the treatment and prevention of osteoporosis, this disease is often underdiagnosed, undertreated and associated with poor patient compliance and adherence to therapy [5]. Current strategies for the management of osteoporosis include preventive actions as well as non-pharmacological and pharmacological treatment.

\section{Drug Therapies Approved for Postmenopausal Osteoporosis}

Adequate supply of vitamin D and calcium is recommended as a baseline therapy for the prevention and treatment of osteoporosis in all patients, but is not sufficient for the treatment of prevalent osteoporosis [5, 6]. Vitamin D and calcium supplementation is included in most clinical trials evaluating novel drug candidates. Most drugs approved for the treatment of osteoporosis are antiresorptive agents that improve bone strength and reduce the risk of fractures primarily by decreasing the bone turnover and maintaining or increasing the BMD. These drugs include orally and intravenously applied bisphosphonates, selective estrogen receptor modulators (SERMs), and salmon calcitonin (table 1) [5-7]. In contrast, anabolic agents such as teriparatide and recombinant human parathyroid hormone (PTH) act by increasing bone formation. Strontium ranelate has antiresorptive and anabolic properties and is therefore classified as a dual-acting bone agent (DABA). Numerous clinical trials have demonstrated the efficacy of the drugs mentioned above. However, therapy with these agents is limited by side effects, schemes for intake, restricted duration of treatment and, not least, cost of the drugs.

Oral bisphosphonates generally have a low bioavailability. Adverse gastrointestinal effects and restrictive application schemes contribute to suboptimal patient compliance and/or premature cessation of therapy in many patients. A systematic review found that the average duration of therapy with osteoporosis treatments, primarily bisphosphonates, was generally less than 1 year [8]. More recently intravenous

Table 1. Other drugs approved in the EU for prevention and/or therapy of postmenopausal osteoporosis [36]

\begin{tabular}{|c|c|c|c|c|c|}
\hline \multirow[t]{2}{*}{ Class } & \multirow[t]{2}{*}{ INN } & \multicolumn{3}{|c|}{ Clinical evidence } & \multirow[t]{2}{*}{ Limitations and potential side effects } \\
\hline & & $\uparrow \mathrm{BMD}$ & $\begin{array}{l}\downarrow \text { Risk of vertebral } \\
\text { fractures }\end{array}$ & $\begin{array}{l}\downarrow \text { Risk of nonvertebral } \\
\text { fractures }\end{array}$ & \\
\hline \multicolumn{6}{|c|}{ Bisphosphonates } \\
\hline \multirow[t]{2}{*}{ Oral } & alendronate & + & +++ & ++ & \multirow[t]{2}{*}{ gastrointestinal AE: gastritis, intake } \\
\hline & etidronate & + & + & - & \\
\hline \multirow[t]{3}{*}{ Intravenous } & risedronate & + & +++ & ++ & \multirow[t]{3}{*}{ flu-like symptoms, myalgia } \\
\hline & ibandronate $^{\mathrm{a}}$ & + & $+/+++^{\#}$ & $+/+++^{\#}$ & \\
\hline & zoledronate & + & +++ & +++ & \\
\hline DABAs & strontium ranelate & + & +++ & +++ & thrombosis risk, DRESS \\
\hline \multirow[t]{2}{*}{ SERMs } & raloxifene & + & +++ & - & \multirow{2}{*}{$\begin{array}{l}\text { vasomotor symptoms, thromboembolic } \\
\text { events, cramps }\end{array}$} \\
\hline & lasofoxifene & + & +++ & +++ & \\
\hline \multirow[t]{2}{*}{ PTH } & teriparatide & + & +++ & ++ & \multirow{2}{*}{$\begin{array}{l}\text { nausea, dizziness, leg cramps; maximum } \\
\text { duration: } 24 \text { months }\end{array}$} \\
\hline & rHuPTH 1-84 & + & +++ & - & \\
\hline Calcitonin & salmon calcitonin & + & + & - & rhinitis \\
\hline
\end{tabular}

${ }^{a}$ Approved for oral (\#) and intravenous administration.

+++ Strong evidence, ++ good evidence, + some evidence, - no evidence.

DABAs = Dual-acting bone agents, SERMs = selective estrogen receptor modulators, $\mathrm{PTH}=$ parathyroid hormone,

$\mathrm{rHuPTH}=$ recombinant human PTH, AE = adverse event, DRESS = drug rash with Eosinophilia and systemic symptoms 
bisphosphonates with an increased potency have been approved, which allows for longer dosing intervals and thereby potentially leading to better compliance. SERMs such as raloxifene and the quite recently approved lasofoxifene are associated with a higher risk of vasomotor effects, thromboembolic events and stroke [9], and strontium ranelate increases the risk of venous thrombosis [10] or rare skin diseases [11]. Therapy with recombinant human PTH and teriparatide is limited to a maximum of 24 months without any repetition.

\section{The OPG/RANKL System in Bone Metabolism}

Bone remodeling is a continuous process of bone resorption and formation that renews the skeleton while maintaining its structure $[12,13]$. Osteoclasts, specialized cells to resorb bone, are controlled by several cytokines. The central cytokine for osteoclastogenesis is the receptor activator of nuclear factor $\kappa \mathrm{B}$ ligand (RANKL) [14], a member of the tumor necrosis factor (TNF) superfamily. RANKL is expressed by osteoblasts and osteoblast precursors. Binding of RANKL to its receptor, RANK, induces osteoclast differentiation, activation, and survival [15]. This results in increased bone resorption. RANK is expressed on mature and precursor osteoclasts. RANKL is endogenously regulated by the secreted glycoprotein osteoprotegerin (OPG), a non-signaling 'decoy receptor' of RANKL [16]. Alterations of the RANKL/OPG ratio are critical in the pathogenesis of bone diseases that result from increased bone resorption. In addition, a number of cytokines, prostaglandin E2 and other hormones act with RANKL to control osteoclast activity $[13,17]$. Denosumab is a fully human monoclonal antibody with a high specificity for human RANKL [13]. Upon binding to RANKL, denosumab inhibits bone resorption by suppressing osteoclast formation, activity, and survival (fig. 1).

\section{Clinical Data on Denosumab in Postmenopausal Osteoporosis}

To date, more than 10,000 patients with postmenopausal osteoporosis (PMO) have been treated with denosumab. Published clinical data on denosumab in patients with PMO include 1 phase I dose escalation trial, 1 phase II trial with extension studies and 4 phase III trials (table 2; summarized in [18]).

The pharmacokinetic profile of denosumab was evaluated in a randomized, double-blind, placebo-controlled, dose escalation phase I study in 49 postmenopausal women receiving a single subcutaneous (s.c.) dose of denosumab (0.01-3.0 mg/ $\mathrm{kg}$ ) [19]. After s.c. application, the pharmacokinetics of denosumab was nonlinear with dose, reaching a maximum serum concentration (Cmax) at 5-21 days post dose. The serum half-

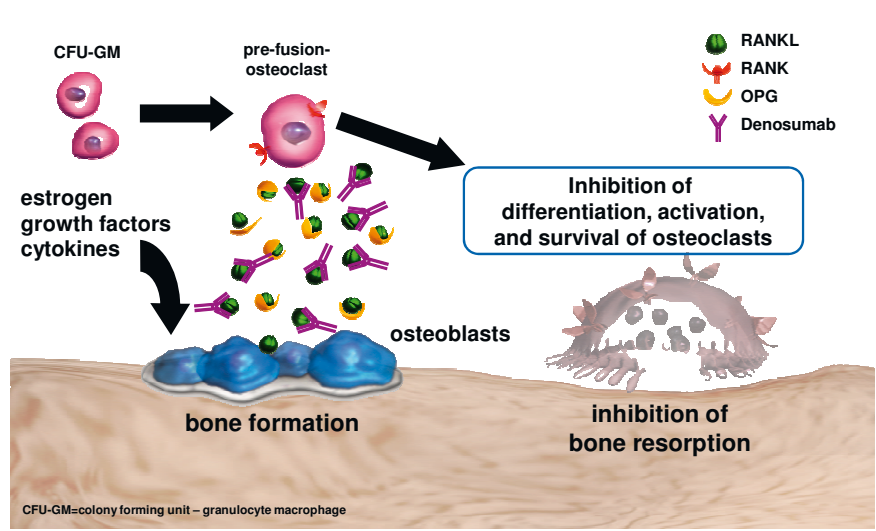

Fig. 1. Novel mode of action: Denosumab specifically binds to RANKL and inhibits osteoclast differentiation, activation and survival. Denosumab is an investigational drug not yet approved [12].

life was 32 days with the maximum dose. The effect on bone resorption was measured by urinary and serum N-telopeptide (NTX): Denosumab reduced these bone turnover markers within $12 \mathrm{~h}$ in a dose-dependent manner. The decrease versus baseline was up to $84 \%$ after 3 months and started to increase to baseline levels after 6 months.

Long-term treatment with denosumab (up to 6 years) was examined in a phase II randomized, placebo-controlled, doseranging study [20]. 412 postmenopausal women with low BMD and a lumbar spine T-score of -1.8 to -4.0 were randomized to 9 treatment groups: s.c. denosumab 6,14, or $30 \mathrm{mg}$ every 3 months; s.c. denosumab 14, 60, 100, or 210 mg every 6 months; open-label alendronate $70 \mathrm{mg}$ weekly; or placebo. Denosumab treatment for 12 months resulted in a BMD increase of 3.0 to $6.7 \%$ at the lumbar spine compared to baseline, while there was a $4.6 \%$ increase with alendronate and a $0.8 \%$ loss with placebo ( $\mathrm{p}<0.001$ vs. placebo). At the total hip, there was a BMD increase of 1.9 to $3.6 \%$ compared to baseline, with a $2.1 \%$ increase with alendronate and a $0.6 \%$ loss in the placebo group $(p<0.001)$. In comparison with alendronate, the BMD changes were at least as large with denosumab, with an apparently greater BMD increase at the total hip and distal one-third radius with denosumab $30 \mathrm{mg}$ every 3 months and $60 \mathrm{mg}$ every 6 months. Of the original 412 women randomized, 337 completed the 24-month study [21] and 262 were treated for 48 months [22]. Continuous, longterm denosumab treatment increased BMD at the lumbar spine and total hip by 9.4 to $11.8 \%$ and 4.0 to $6.1 \%$, respectively. Bone turnover markers were reduced over 48 months. An extension of the denosumab phase II study to a total of 72 months of treatment with denosumab has been completed. This phase II trial also revealed that discontinuation of denosumab led to a decrease of BMD, increasing again after treatment with denosumab is restarted, showing the reversibility of the drug [22]. The dose of $60 \mathrm{mg}$ every 6 months was selected for the phase III clinical trials since higher doses were not associated with additional increases in BMD. 
Table 2. Overview of clinical trials with denosumab for postmenopausal osteoporosis (PMO)

\begin{tabular}{llll}
\hline Indication & Phase & $\mathrm{N}$ & Design \\
\hline PMO/therapy & III & 7868 & $1: 1$ randomized, double-blind, placebo-controlled \\
(FREEDOM) & & & study for 36 months; BMD (lumbar spine) \\
& & & $<-2.5$ and $>4.0 ;$ Dmab 60 mg s.c. every 6 months \\
& & vs. placebo
\end{tabular}

$\begin{array}{lll}\text { PMO/prevention } & \text { III } \quad 332 \quad 1: 1 \text { randomized, double-blind, placebo-controlled } \\ \text { (DEFEND) } & & \text { study for } 24 \text { months; BMD (lumbar spine) } \\ & \leq-1.0 \text { and } \geq 2.5 ; \text { Dmab } 60 \mathrm{mg} \text { s.c. every } 6 \text { months } \\ & \text { vs. placebo }\end{array}$

PMO/therapy vs. III $\quad 1189 \quad 1: 1$ randomized, double-blind, active-controlled alendronate (DECIDE) study for 12 months; BMD (lumbar spine or total hip) $\leq-2.0 ; 60 \mathrm{mg}$ Dmab s.c. every 6 months vs. ALN 70 mg orally once weekly

\begin{abstract}
PMO/therapy
bisphosphonate
\end{abstract}

transition (STAND)

PMO/therapy
$\mathrm{IIIb}$

504

1:1 randomized, double-blind, active-controlled study for 12 months; BMD (lumbar spine or total hip) $\leq-2.0$ and $\geq-4.0 ; \geq 6$ months previous therapy with ALN; $60 \mathrm{mg}$ Dmab s.c. every 6 months vs. ALN 70 mg orally once weekly

412 randomized controlled study for up to 6 years (incl. extensions); BMD (lumbar spine) $\leq-1.8$ and $\geq-4.0$; or BMD (prox. femur) $\leq-1.8$ and $\geq-3.5$; Dmab s.c. $(6,14,30 \mathrm{mg}$ every 3 months or 14,60 , $100,210 \mathrm{mg}$ every 6 months) vs. placebo vs. open ALN, $70 \mathrm{mg}$ once weekly

Main clinical results

Publication

risk of new vertebral fractures reduced by

$68 \%$ with Dmab vs. placebo; incidence of

new vertebral fractures: Dmab $2.3 \%$ vs.

placebo $7.2 \% ;$ p $<0.0001$; risk of hip fracture

reduced by $40 \%$ with Dmab vs. placebo;

$\mathrm{p}=0.036$; risk of nonvertebral fractures

reduced by $20 \% ; \mathrm{p}=0.011$

BMD improvement (lumbar spine): Dmab

$6.5 \%$ vs. placebo $-0.6 \% ; p<0.0001 ;$ BMD

improvement in Dmab group at total hip,

one-third radius, total body; $\mathrm{p}<0.0001$ vs. placebo

relative BMD improvement (total hip)

$\sim 35 \%$ greater in the Dmab vs. ALN group;

Dmab 3.5\% vs. ALN 2.6\%; p < 0.0001;

BMD significantly greater with Dmab vs.

ALN at all skeletal sites; $p \leq 0.0002$

relative BMD improvement (total hip)

$\sim 80 \%$ greater in the Dmab vs. ALN group;

Dmab 1.90 vs. ALN 1.05, p < 0.0001; BMD

significantly greater with Dmab vs. ALN

at lumbar spine, femoral neck, 1/3 radius; $\mathrm{p}<0.0125$

BMD improvement at 12/24 months

(lumbar spine); Dmab 3.0-6.7\%/

4.13-8.89\%; ALN 4.6\%/24 months data

not shown; placebo $-0.8 \% /-1.18 \%$; BMD

improvement (total hip) at 12 months;

Dmab 1.9-3.6\%; ALN 2.1\%, placebo-0.6\%;

BMD improvement (lumbar spine) at 48

months; Dmab 9.4-11.8\%

decrease in urinary NTX dose dependent,

within $12 \mathrm{~h}$, up to $84 \%$ and for up to 6 months

Cummings et al., 2009

[24]

Bone et al., 2008 [23]

Brown et al., 2009 [25]

Kendler et al., 2010

McClung et al., 2006 [20], Lewiecki et al., 2007 [21], Miller et al., 2008 [22]

\begin{tabular}{lll}
$\begin{array}{l}\text { Healthy postmenopausal } \\
\text { women/PK }\end{array}$ & I & $49 \begin{array}{l}1: 3 \text { randomized dose-ranging study; single-dose } \\
\text { Dmab s.c. } 0.01,0.03,0.1,0.3,1.0,3.0 \mathrm{mg} / \mathrm{kg} \text { vs. } \\
\text { placebo }\end{array}$ \\
\hline
\end{tabular}

\begin{tabular}{lll}
$\begin{array}{l}\text { Healthy postmenopausal } \\
\text { women/PK }\end{array}$ & I & $49 \begin{array}{l}1: 3 \text { randomized dose-ranging study; single-dose } \\
\text { Dmab s.c. } 0.01,0.03,0.1,0.3,1.0,3.0 \mathrm{mg} / \mathrm{kg} \text { vs. } \\
\text { placebo }\end{array}$ \\
\hline
\end{tabular}

\begin{tabular}{lll}
$\begin{array}{l}\text { Healthy postmenopausal } \\
\text { women/PK }\end{array}$ & I & $49 \begin{array}{l}1: 3 \text { randomized dose-ranging study; single-dose } \\
\text { Dmab s.c. } 0.01,0.03,0.1,0.3,1.0,3.0 \mathrm{mg} / \mathrm{kg} \text { vs. } \\
\text { placebo }\end{array}$ \\
\hline
\end{tabular}

$\mathrm{ALN}=$ Alendronate, $\mathrm{PK}=$ pharmacokinetics, Dmab $=$ denosumab, $\mathrm{NTX}=\mathrm{N}$-telopeptide.
Of the 4 phase III studies, the FREEDOM study investigated the prevention of fractures comparing denosumab versus placebo. FREEDOM and DEFEND looked at the effect of denosumab versus placebo on BMD and on bone turnover markers $[23,24]$. The two remaining studies were head-tohead trials comparing alendronate therapy with denosumab in untreated patients (DECIDE study) and in patients pretreated with bisphosphonates (STAND study) [25, 26]. In STAND, patients on alendronate for at least 6 months either switched to denosumab or continued their bisphosphonate therapy, whereas in DECIDE patients were either treatment naive $(3 / 4)$ or received other osteoporosis medications.

In all clinical trials, patients in either arm, denosumab or control, received daily supplements of calcium and vitamin D.

The DEFEND study was a randomized, double-blind, placebo-controlled study for 24 months. 332 postmenopausal osteopenic women with lumbar spine BMD T-scores between -1.0 and -2.5 received either denosumab s.c., $60 \mathrm{mg}$ every 6 months, or placebo [23]. At 24 months, denosumab significantly increased the BMD at the lumbar spine, compared with placebo (6.5 vs. $-0.6 \%$; $<<0.0001)$. Denosumab treatment also led to significant increases in BMD at the total hip, one-third radius, and total body ( $\mathrm{p}<0.0001$ vs. placebo). Bone turnover markers significantly decreased with denosumab.
The FREEDOM trial enrolled 7868 postmenopausal women with a T-score between $<-2.5$ and -4.0 at the lumbar spine or total hip [24]. In this randomized, double-blind, placebo-controlled study, patients received either $60 \mathrm{mg}$ of denosumab or placebo s.c. every 6 months for 36 months. In comparison to placebo, denosumab reduced the risk of new radiographic vertebral fractures by $68 \%$. The cumulative incidence of fractures with denosumab and placebo was $2.3 \%$ and $7.2 \%$, respectively (risk ratio, $0.32 ; 95 \%$ confidence interval (CI), $0.26-0.41 ; \mathrm{p}<0.001)$. Denosumab reduced the risk of hip fracture by $40 \%$, with a cumulative incidence of $0.7 \%$ in the denosumab group, versus $1.2 \%$ in the placebo group (hazard ratio (HR), 0.60; 95\% CI, 0.37-0.97; $\mathrm{p}=0.04$ ). Furthermore, the risk of nonvertebral fractures was reduced by $20 \%$, with a cumulative incidence of $6.5 \%$ in the denosumab group, versus $8.0 \%$ in the placebo group (HR, 0.80; 95\% CI, 0.67-0.95; $\mathrm{p}=0.01)$.

The DECIDE trial, a randomized, double-blind, activecontrolled study, compared the efficacy and safety of denosumab with alendronate in 1189 postmenopausal women with low bone mass (T-score $\leq-2.0$ at the lumbar spine or total hip) [25]. Patients received either denosumab s.c., $60 \mathrm{mg}$ every 6 months, plus oral placebo weekly or oral alendronate weekly, $70 \mathrm{mg}$, plus s.c. placebo injections every 6 months for 
a total of 12 months. Denosumab showed significantly larger gains in BMD and greater reduction in bone turnover markers compared with alendronate. The increase in BMD at total hip was approximately $35 \%$ higher with denosumab compared to alendronate at month 12 (3.5\% versus $2.6 \%$; $\mathrm{p}<0.0001)$. In addition, increases in BMD at all measured sites were significantly greater with denosumab treatment (treatment difference: $0.6 \%$, femoral neck; $1.0 \%$, trochanter; $1.1 \%$, lumbar spine; $0.6 \%$, one-third radius; $\mathrm{p} \leq 0.0002$ for all sites). Denosumab treatment led to significantly greater reduction of bone turnover markers compared with alendronate therapy.

STAND was a randomized, double-blind, active-controlled study in 504 postmenopausal women with a BMD T-score of $\leq-2.0$ to -4.0 [26]. The subjects had to receive alendronate for at least 6 months. After an open-label alendronate phase, $70 \mathrm{mg}$ once weekly for 1 month, the patients were randomized to either continue weekly alendronate therapy or switch to denosumab s.c., $60 \mathrm{mg}$ every 6 months, for 12 months. Transition to denosumab led to greater increases in BMD at all measured skeletal sites and a greater reduction in bone turnover than did continued alendronate. Total hip BMD increased by $1.90 \%$ and $1.05 \%$ in subjects receiving denosumab versus alendronate $(\mathrm{p}<0.0001)$. Compared to alendronate, denosumab led to significantly greater BMD gains within 12 months at the lumbar spine, femoral neck, and one-third radius ( $\mathrm{p}<0.0125$ for all sites). Median serum C-telopeptide (CTX) levels remained near baseline in the alendronate group and were significantly decreased versus alendronate $(\mathrm{p}<0.0001)$ at all time points with denosumab.

Clinical data demonstrate that denosumab effectively increases BMD, decreases bone turnover and significantly reduces the risk of vertebral, nonvertebral and hip fractures. Bone resorption by denosumab is inhibited in a rapid, sustained and reversible manner.

\section{Safety of Denosumab}

RANKL is not only expressed on osteoclasts but also on endothelial cells, osteoblasts, activated $\mathrm{T}$ lymphocytes, immature thymocytes, and other cell types. In addition, RANK is expressed on various cells such as mature $\mathrm{T}$ cells, dendritic cells, mammary gland epithelial cells, and chondrocytes [27]. Therefore, potential impacts of RANKL inhibition on immune function, malignancy, mammary cell activity, or vascular calcification need to be carefully investigated.

In phase III trials in patients with PMO, the rates of adverse events and serious adverse events were similar between denosumab and the control group (placebo or alendronate) [23-26]. There was no increase in the risk of cancer, infection, cardiovascular disease, delayed fracture healing, or hypocalcemia. In the DEFEND study, the rate of serious adverse events was higher in the denosumab arm compared to pla- cebo, although not significantly [23]. This was primarily due to a greater number of infections treated in a hospital. In the FREEDOM study, the rate of serious cellulite was higher compared to the placebo arm $(0.3 \%$ vs. $<0.1 \%, \mathrm{p}=0.002)$, but the overall incidence of cellulite was similar [24]. No cases of osteonecrosis of the jaw occurred in the phase III trials. No neutralizing antibodies were observed in clinical trials. Taken together, denosumab seems to have a favorable safety profile.

\section{Denosumab: Other Indications}

Based on data in postmenopausal women with osteoporosis, denosumab was also evaluated in oncologic patients undergoing hormone-ablative therapies. A phase III trial in 252 patients receiving aromatase inhibitors for non-metastatic breast cancer demonstrated that twice-yearly treatment with denosumab s.c., 60 mg every 6 months, was associated with consistently greater gains in BMD than treatment with placebo [28]. Compared to placebo, lumbar spine BMD increased by $5.5 \%$ and $7.6 \%$ after 12 and 24 months, respectively, in the denosumab group ( $p<0.0001$ for both). Increases in BMD were also observed at the total hip, total body, femoral neck, and the predominantly cortical one-third radius. Comparable results were observed in a phase III trial in patients receiving androgen deprivation therapy for non-metastatic prostate cancer [29]. At 24 months, denosumab was associated with increased BMD, $5.6 \%$ in the denosumab group as compared with a loss of $1.0 \%$ in the placebo group $(\mathrm{p}<0.001)$. After 36 months there were less new vertebral fractures in the denosumab-treated group as compared to placebo (1.5\% vs. $3.9 \%$; relative risk, 0.38 ; 95\% CI, 0.19-0.78; $\mathrm{p}=0.006)$.

Since preclinical data suggest anti-tumor effects of denosumab in bone by inhibition of osteoclasts, denosumab is investigated in various oncologic indications affecting bone [30, 31]. Phase III studies looked at patients with bone metastases in breast cancer and advanced solid tumors or multiple myeloma [32, 33]. For these indications, denosumab was administered at a dose of $120 \mathrm{mg}$ s.c. twice yearly. In breast cancer patients with bone metastases, denosumab significantly delayed the time to first on-study skeletal-related event (SRE; pathologic fracture, radiation therapy or surgery to bone, or spinal cord compression) compared with zoledronic acid (HR, $0.82 ; 95 \% \mathrm{CI}, 0.71-0.95 ; \mathrm{p}=0.01$ ) in this 34 -month study [32]. Denosumab also significantly delayed the time to first and subsequent on-study SRE (multiple event analysis) compared with zoledronic acid (HR, 0.77; 95\% CI, 0.66-0.89; $\mathrm{p}=0.001$ ). However, overall survival and time to cancer progression were similar between the two treatment groups. Another phase III trial in patients with solid tumors and bone metastases (excluding breast and prostate) or multiple myeloma with osteolytic bone disease revealed that denosumab was not inferior to zoledronic acid in the delay of on-study SRE [33]. 
Although numerically greater, the delay in time to first on-study SRE with denosumab was not superior to zoledronic acid based on the statistical testing strategy (adjusted $p=0.06$ ). Other indications under investigation include the prevention of bone metastases, the treatment of giant cell tumors of the bone as well as therapy of rheumatic diseases [34, 35].

\section{Conclusions}

The monoclonal antibody denosumab exhibits a new mode of action by selectively targeting molecules involved in bone turnover. Clinical results of this drug are promising, demonstrating at least similar or even superior efficacy in comparison to conventional therapies. In addition, the favorable safety profile and infrequent and simplified dosing regimen might contribute to improved patient compliance, persistence with therapy, and finally better long-term clinical outcomes.

\section{Conflict of Interest}

The author discloses the following potential conflicts of interest: paid consultant for Lilly, Amgen, Roche, Novartis, Nycomed, and Servier; speaker for Merck (MSD), Lilly, Servier, Roche, and Nycomed; and having received grant/research support from Lilly and Roche.

\section{References}

1 Felsenberg D, Boonen S: The bone quality framework: determinants of bone strength and their interrelationships, and implications for osteoporosis management. Clin Ther 2005;27:1-11.

2 Assessment of fracture risk and its application to screening for postmenopausal osteoporosis. Report of a WHO Study Group. Geneva, World Health Organization, 1994 (WHO Technical Report Series, No. 843).

$\checkmark 3$ Cummings SR, Melton LJ: Epidemiology and outcomes of osteoporotic fractures. Lancet 2002; 359:1761-1767.

$\checkmark 4 \mathrm{NIH}$ Consensus Development Panel on Osteoporosis Prevention, Diagnosis, and Therapy: Osteoporosis prevention, diagnosis, and therapy JAMA 2001;285:785-795.

$\checkmark 5$ Lewiecki EM: Current and emerging pharmacologic therapies for the management of postmenopausal osteoporosis. J Womens Health 2009;18: $1615-1626$.

6 Sambrook P, Cooper C: Osteoporosis. Lancet 2006;367:2010-2018.

7 Delmas PD: Treatment of postmenopausal osteoporosis. Lancet 2002;359:2018-2026.

$>8$ Cramer JA, Gold DT, Silverman SL, Lewiecki EM: A systematic review of persistence and compliance with bisphosphonates for osteoporosis. Osteoporos Int 2007;18:1023-1031.

-9 Mosca L, Grady D, Barrett-Connor E, Collins P, Wenger N, Abramson BL, Paganini-Hill A, Geiger MJ, Dowsett SA, Amewou-Atisso M, Kornitzer M: Effect of raloxifene on stroke and venous thromboembolism according to subgroups in postmenopausal women at increased risk of coronary heart disease. Stroke 2009;40:147-155.

10 Protelos EPAR. www.ema.europa.eu.

11 EMEA press release. www.ema.europa.eu/humandocs/ PDFs/EPAR/protelos/Press Release_Protelos 41745807en.pdf

12 Boyle WJ, Simonet WS, Lacey DL: Osteoclast differentiation and activation. Nature 2003;423: 337-341.

13 Hofbauer LC, Schoppet M: Clinical implications of the osteoprotegerin/RANKL/RANK system for bone and vascular diseases. JAMA 2004;292:490 495.
14 Lacey DL, Timms E, Tan HL, Kelley MJ, Dunstan CR, Burgess T, Elliott R, Colombero A, Elliott G, Scully S, Hsu H, Sullivan J, Hawkins N, Davy E, Capparelli C, Eli A, Qian YX, Kaufman S, Sarosi I, Shalhoub V, Senaldi G, Guo J, Delaney J, Boyle WJ: Osteoprotegerin ligand is a cytokine that regulates osteoclast differentiation and activation. Cell 1998;93:165-176.

15 Hsu H, Lacey DL, Dunstan CR, Solovyev I, Colombero A, Timms E, Tan H-L, Elliott G, Kelley MJ, Sarosi I, Wang L, Xia X-Z, Elliott R, Chiu L, Black T, Scully S, Capparelli C, Morony S, Shimamotos G, Bass MB, Boyle WJ: Tumor necrosis factor receptor family member RANK mediates osteoclast differentiation and activation induced by osteoprotegerin ligand. Proc Natl Acad Sci USA 1999:96:3540-3545.

16 Simonet WS, Lacey DL, Dunstan CR, Kelley M, Chang MS, Lüthy R, Nguyen HQ, Wooden S, Bennett L, Boone T, Shimamoto G, DeRose M, Elliott R, Colombero A, Tan HL, Trail G, Sullivan J, Davy E, Bucay N, Renshaw-Gegg L, Hughes TM, Hill D, Pattison W, Campbell P, Sander S, Van G, Tarpley J, Derby P, Lee R, Boyle WJ: Osteoprotegerin: a novel secreted protein involved in the regulation of bone density. Cell 1997;89:309319.

17 Teitelbaum SL: Bone resorption by osteoclasts. Science 2000;289:1504-1508

18 Lewiecki EM: Denosumab in postmenopausal osteoporosis: what the clinician needs to know. Ther Adv Musculoskel Dis 2009;1:13-26.

19 Bekker PJ, Holloway DL, Rasmussen AS, Murphy R, Martin SW, Leese PT, Holmes GB, Dunstan CR, DePaoli AM: A single-dose placebo-controlled study of AMG 162, a fully human monoclonal antibody to RANKL, in postmenopausal women. J Bone Miner Res 2004;19:1059-1066.

20 McClung MR, Lewiecki EM, Cohen SB, Bolognese MA, Woodson GC, Moffett AH, Peacock M, Miller PD, Lederman SN, Chesnut CH, Lain D, Kivitz AJ, Holloway DL, Zhang C, Peterson MC, Bekker PJ for the AMG 162 Bone Loss Study Group: Denosumab, a RANKL inhibitor, in postmenopausal women with low bone mineral density. N Engl J Med 2006;354:821-831.
1 Lewiecki EM, Miller PD, McClung MR, Cohen SB, Bolognese MA, Liu Y, Wang A, Siddhanti S, Fitzpatrick LA for the AMG 162 Bone Loss Study Group: Two year treatment with denosumab (AMG 162) in a randomized phase 2 study of postmenopausal women with low bone mineral density. J Bone Miner Res 2007;22:1832-1841.

22 Miller PD, Bolognese MA, Lewiecki EM, McClung MR, Ding B, Austin M, Liu Y, San Martin J for the AMG 162 Bone Loss Study Group: Effect of denosumab on bone density and turnover in postmenopausal women with low bone mass after long-term continued, discontinued, and restarting of therapy: A randomized blinded phase 2 clinical trial. Bone 2008;43:222-229.

23 Bone HG, Bolognese MA, Yuen CK, Kendler DL, Wang H, Liu Y, San Martin J: Effects of denosumab on bone mineral density and bone turnover in postmenopausal women. J Clin Endocrinol Metab 2008;93:2149-2157.

24 Cummings SR, San Martin J, McClung MR, Siris ES, Eastell R, Reid IR, Delmas P, Zoog HB, Austin M, Wang A, Kutilek S, Adami S, Zanchetta J, Libanati C, Siddhanti S, Christiansen C for the FREEDOM Trial: Denosumab for prevention of fractures in postmenopausal women with osteoporosis. N Engl J Med 2009;361:756-765.

25 Brown JP, Prince RL, Deal C, Recker RR, Kiel DP, de Gregorio LH, Hadji P, Hofbauer LC, Álvaro-Gracia JM, Wang H, Austin M, Wagman RB, Newmark R, Libanati C, San Martin J, Bone HG: Comparison of the effect of denosumab and alendronate on BMD and biochemical markers of bone turnover in postmenopausal women with low bone mass: a randomized, blinded, phase 3 trial. J Bone Miner Res 2009;24:153-161.

26 Kendler DL, Roux C, Benhamou CL, Brown JP, Lillestol M, Siddhanti S, Man H-S, San Martin J, Bone HG: Effects of denosumab on bone mineral density and bone turnover in postmenopausal women transitioning from alendronate therapy. J Bone Miner Res 2010;25:72-81.

27 Wright HL, McCarthy HS, Middleton J, Marshall MJ: RANK, RANKL and osteoprotegerin in bone biology and disease. Curr Rev Musculoskelet Med 2009;2:56-64. 
-28 Ellis GK, Bone HG, Chlebowski R, Paul D, Spadafora S, Smith J, Fan M, Jun S: Randomized trial of denosumab in patients receiving adjuvant aromatase inhibitors for nonmetastatic breast cancer. J Clin Oncol 2008;26:4875-4882.

29 Smith MR, Egerdie B, Toriz NH, Feldman R, Tammela TLJ, Saad F, Heracek J, Szwedowski M, Ke C, Kupic A, Leder BZ, Goessl C for the Denosumab HALT Prostate Cancer Study Group: Denosumab in men receiving androgen-deprivation therapy for prostate cancer. N Engl J Med 2009;361:745-755.

30 Roodman GD: Mechanisms of bone metastasis N Engl J Med 2004;350:1655-1664.

31 Dougall WC, Chaisson M: The RANK/RANKL/ OPG triad in cancer-induced bone diseases. Cancer Metastasis Rev 2006;25:541-549.
32 Stopeck A, Body JJ, Fujiwara Y, Lipton A, Steger GG, Viniegra M, Fan M, Braun A, Dansey R, Jun S: Denosumab versus zoledronic acid for the treatment of breast cancer patients with bone metastases: results of a randomized phase 3 study. Eur J Can Suppl 2009;7:2 abstr.

33 Henry D, von Moos R, Vadhan-Raj S, Hungria V, Spencer A, Hirsh V, Wang J, Jun S, Yeh H, Dansey R: A double-blind, randomized study of denosumab versus zoledronic acid for the treatment of bone metastases in patients with advanced cancer (excluding breast and prostate cancer) or multiple myeloma. Eur J Can Suppl 2009;7:11 abstr.

34 Thomas D, Henshaw R, Skubitz K, Chawla S, Staddon A, Blay J-Y, Roudier M, Smith J, Ye Z, Sohn W, Dansey R, Jun S: Denosumab in patients with giant-cell tumour of bone: an open-label, phase 2 study. Lancet Oncol 2010;11:275-280.
5 Cohen SB, Dore RK, Lane NE, Ory PA, Peterfy CG, Sharp JT, van der Heijde D, Zhou L, Tsuji W, Newmark R; Denosumab Rheumatoid Arthritis Study Group: Denosumab treatment effects on structural damage, bone mineral density, and bone turnover in rheumatoid arthritis: a twelve-month, multicenter, randomized, double-blind, placebocontrolled, phase II clinical trial. Arthritis Rheum 2008;58:1299-1309.

36 Dimai HP, Pietschmann P, Resch H, Preisinger E, Fahrleitner-Pammer A, Dobnig H, Klaushofer $\mathrm{K}$ für die Austrian Society for Bone and Mineral Research (AuSBMR): Österreichischer Leitfaden zur medikamentösen Therapie der postmenopausalen Osteoporose - Update 2009. Wien Med Wochenschr 2009;159:1-34 